\title{
Short-Term Effect of China Violet Compost on Soil Properties of Ultisol and Peanut Yield
}

\author{
Heri Junedi ${ }^{\#}$, Zurhalena ${ }^{\#}$, Itang Ahmad Mahbub ${ }^{\#}$ \\ \# Study Program of Agroecotechnology, Faculty of Agriculture, University of Jambi \\ Kampus Pinang Masak, Jalan Raya Jambi-Muaro Bulian Km 15 Mendalo Darat Jambi 36361, Indonesia \\ E-mail:heri_junedi@yahoo.com
}

\begin{abstract}
Compost application can contribute to agricultural sustaniability that it has proven to improve soil quality and crops yield. One of the ingredients can be made of china violet that mostly found as weeds in oil palm and rubber plantation. The aims of this study were to evaluate the effect of compost application on soil properties of Ultisol and peanut yield. The experiment was carried out at the Experimental Field of Agriculture Faculty, University of Jambi, Mendalo Darat, Jambi. The treatments were arranged in a rondomly blocked design consisting of (i) control (without compost), (ii) $5 \mathrm{Mg}$ ha-1 compost, (iii) $10 \mathrm{Mg}$ ha-1 compost, (iv) $15 \mathrm{Mg}$ ha-1 compost, and (v) $20 \mathrm{Mg}$ ha-1 compost. The results of study showed that the application of compost improve the soil chemical properties by increasing soil $\mathrm{pH}, \mathrm{CEC}, \mathrm{N}, \mathrm{P}$, and $\mathrm{K}$. In addition peanut yield was increased by compost application. The highest increase in peanut yield was achieved by application of $20 \mathrm{Mg}$ ha-1 compost.
\end{abstract}

Keywords - Sustainability; Compost; Soil Properties; Ultisol; Peanut

\section{INTRODUCTION}

Peanut (Arachis hypogaea (L.) Merr.) is one of the most important pulse crops grown in Indonesia besides soybean (Glycine $\max (\mathrm{L}$.$) Merr.). However, the production of$ peanut from 2007-2011 fluctuates with average 758,632 Mg year ${ }^{-1}$ and the average yield $1,23 \mathrm{Mg} \mathrm{ha}^{-1}$ so that it has to be imported 251,748 Mg in 2011 [1]. The problem is not only low of average yield but also low of harvested area.

To increase production and average yield of peanut it can do through both the expansion of harvested area (extensification) and increase the utilization of existing arable land (intensification). However, fertile arable land has been converted to other utilization so that the expansion of arable land turned to marginal drylands. One of the potential dryland to be developed is Ultisol. But the main problem in developing dryland farming in Ultisol is the limitation of soil physical dan chemical properties.

One one of efforts to improve the productivity of Ultisol is the application of organic matter. Application of organic matter incerases the soil organic matter (SOM) status in the top soil. SOM has multiple beneficial effects on water holding capacity, aeration, permeability, soil fertility, crop production and overall soil sustainability [2], [3], [4].

In the last decade, the application of wastes with a high organic matter content to soil has been performed in an effort to supply plant nutrients at a reduced cost and to maintain soil organic matter levels, such as animal manure [5], [6], compost, [7], [8], [9], crop residues [10], [11], green manure [12], industrial by-products [13], and sewage sludge [14].

One of organic matter source is compost. Applying compost can contribute to agricultural sustainability. It improves soil physical and chemical properties as well as crop yield. Adequate use of compost with proper management has been shown to have many advantages. These advantages include adding an array of nutrients to soils [15], increasing SOM, improving water holding capacity and other physical properties of soil such as bulk density, penetration resistance and soil aggregation [10], [11], [16], [17], and beneficial effects on the growth of a variety of plants [18]- [21]. Effect of compost however depend on several parameters such as the compost ingredients, the compost quality, the soil type, and the compost dosage.

Some ingredients can be used to create compost. For example crops residue [22], green manure [12], and sewage sludge, [23]. Another alternative that could be used as a compost ingredient is chinna violet (Asystasia gangetica (L.) T. Anderson). This plant is a common weed in oil palm and rubber plantations. The usage of it as a compost ingredient is still rarely studied. In fact, it has great potential because it contains $37.87 \% \mathrm{C}$ and $1.26 \% \mathrm{~N}$, and $1.57 \% \mathrm{~K}$. The objective of this study was to evaluate the short-term 
effects of china violet compost application on soil properties of Ultisol and peanut yield.

\section{MATERIALS AND METHOD}

\section{A. Compost}

Compost used in the experiments was produced Experimental Farm, University of Jambi, Indonesia. The raw materials used for compost were fresh china violet and fresh cow manure in 1:1 volumetric ratio. To speed up composting, the raw materials watered by extract of a mixture of papaya, banana, bean, cow intestines, palm sugar, and sugar cane at the beginning of composting. The mixture was co-composted in an aerated pile and turned every 3 days, for 3 weeks. During the composting process, the pile was watered regularly to maintain a moisture content. Compost was screened by a $10 \mathrm{~mm}$ screen at the end of composting process prior to application to soil. Analysis of compost was conducted for organic $\mathrm{C}$, total $\mathrm{N}$, total $\mathrm{P}_{2} \mathrm{O}_{5}$, total $\mathrm{K}_{2} \mathrm{O}$, and $\mathrm{pH}$.

\section{B. Field Experimental Design}

The study was carried out at the Experimental Farm of University of Jambi, Indonesia, from July 2012 to December 2012. The soil is acid, low of organic $\mathrm{C}$, total N, available $\mathrm{K}$, and very low of available $P$.

The treatments were arranged in a randomized block design consisting of control (without compost), $5 \mathrm{Mg} \mathrm{ha}^{-1}$ compost, $10 \mathrm{Mg} \mathrm{ha}^{-1}$ compost, $15 \mathrm{Mg} \mathrm{ha}^{-1}$ compost, and 20 $\mathrm{Mg} \mathrm{ha}{ }^{-1}$ compost and replicated four times. Compost was applied to plots on a dry weight basis, incorporated into the soil to a depth of $20-30 \mathrm{~cm}$ two weeks prior to planting. The plot size was 2 by $3 \mathrm{~m}$, planted peanut seed on $20 \mathrm{~cm}$ x 40 $\mathrm{cm}$ spacing. All treatment were suplemented by a chemical fertilizer that was $15 \mathrm{~g} \mathrm{plot}^{-1}$ urea, $30 \mathrm{~g} \mathrm{plot}^{-1} \mathrm{SP}-36$, and 30 $\mathrm{g}$ plot $^{-1} \mathrm{KCl}$.

\section{Sampling and Soil Analysis}

Soil samples $(0-20 \mathrm{~cm})$ were collected on composite soil sample from each plot one day prior to harvesting. After air drying, the soil samples were ground to pass a 2-mm sieve and stored. Soil chemical properties were determined by organic C (Walkley and Black), total $\mathrm{N}$ (Kjeldahl), available $\mathrm{P}$ (P-Bray 1), exchangeble $\mathrm{K}\left(\mathrm{NH}_{4} \mathrm{OA}_{\mathrm{C}} 1 \mathrm{~N} \mathrm{pH} 7\right), \mathrm{pH}\left(\mathrm{H}_{2} \mathrm{O}\right.$ 1:2), and $\mathrm{CEC}\left(\mathrm{NH}_{4} \mathrm{OA}_{\mathrm{C}} 1 \mathrm{~N} \mathrm{pH} \mathrm{7).}\right.$

Undisturbed soil were taken at the $6 \mathrm{~cm}$ depth with metal cores of 4,0 cm diameter and 7,3 cm hight to determine bulk density, porosity, and soil water retention. Soil bulk density was determined using the core method. The soil samples were placed in an oven $105^{\circ} \mathrm{C}$ until achieving constant weight. The bulk density was calculated as the oven-dry mass of the soil sample divided by the core volume. Porosity was calculated from the soil bulk density using the equation, $\%$ porosity $=1-($ soil bulk density/particle density) $\times 100$, where particle density was assumed to be $2.65 \mathrm{~g} \mathrm{~cm}^{-3}$. Soil Soil water retention (as volumetric water content) was measured on the cores using pressure plate method (-33 and $-1500 \mathrm{kPa}$ ) to determine available water content (AWC).

\section{Sampling and Plant Analysis}

The crop was harvested at full maturity, 98 days after planting. The pod and shoot were seperated. The pod was cleaned and dry in sun for 3-4 consecutive days. The yield of pod was adjusted at $12 \%$ moisture level. The data on yield was recorded from 9 randomly selected plats from each plot.

\section{E. Statistical Analysis}

The results were analyzed by using analysis of variance at $\alpha 5 \%$, considering soil and plat samples of each treatment as the independent variables. Mean values were separated by the Duncan Multiple Range Test at $\alpha 5 \%$.

\section{RESULTS AND DISCUSSION}

\section{A. Compost}

The chemical properties of the compost is presented in Tabel I. A low of $\mathrm{C} / \mathrm{N}$ ratio of 18.57 indicated that decomposition process during composting produce a mature compost [24], [25], the quality of compost is moderate [26]. Reference [27] states composting caused a reduction of total organic $\mathrm{C}$ and weight by producing $\mathrm{CO}_{2}$, whereas percentage of total $\mathrm{N}$ was increased.

TABLE 1

COMPOST CHEMICAL PROPERTIES

\begin{tabular}{|l|l|r|}
\hline Proverty & Unit & Value \\
\hline organic $\mathrm{C}$ & $\%$ & 25.63 \\
\hline Total N & $\%$ & 1.38 \\
\hline $\mathrm{C} / \mathrm{N}$ ratio & - & 18.57 \\
\hline total $\mathrm{P}_{2} \mathrm{O}_{5}$ & $\%$ & 0.39 \\
\hline total $\mathrm{K}_{2} \mathrm{O}$ & $\%$ & 1.26 \\
\hline $\mathrm{pH}$ & - & 6.90 \\
\hline
\end{tabular}

\section{B. The Effect of Compost on Soil Properties}

The effect of compost on soil physical properties are summarized in Tabel II.

TABLE II.

THE EFFECT OF COMPOST ON SOIL PHYSICAL PROPERTIES

\begin{tabular}{|l|l|l|l|l|}
\hline Compost & $\begin{array}{l}\text { Total } \\
\text { Organic } \\
\text { Carbon }\end{array}$ & $\begin{array}{l}\text { Bulk } \\
\text { Density }\end{array}$ & $\begin{array}{l}\text { Total } \\
\text { Porosity }\end{array}$ & $\begin{array}{l}\text { Available } \\
\text { Water } \\
\text { Content }\end{array}$ \\
\hline $\mathrm{Mg} \mathrm{ha}^{-1}$ & $\%$ & $\mathrm{~g} \mathrm{~cm}^{-3}$ & $\%$ & $\%$ \\
\hline 0 & 1.71 & 1.31 & 49.44 & 9.44 \\
\hline 5 & 1.90 & 1.28 & 50.57 & 9.66 \\
\hline 10 & 1.96 & 1.26 & 51.12 & 9.90 \\
\hline 15 & 2.02 & 1.24 & 52.14 & 10.53 \\
\hline 20 & 2.09 & 1.22 & 52.77 & 10.82 \\
\hline
\end{tabular}

After amendements were applied, there were no significant differences in organic carbon among treatments. Generally, all treatments increase soil organic carbon content compared to the control. Increased application rates increased soil organic $\mathrm{C}$ content, and the highest organic $\mathrm{C}$ was found at $20 \mathrm{Mg} \mathrm{ha}^{-1}$ application. Numerous studies have shown that soil organic $\mathrm{C}$ increase following the introduction of organic amendements such as sludge [23], [28] paper mill residual and compost [11], [13], pulp and paper mill waste water [29], waste paper aplication [30]. On the other hand, the TOC content of the control plot decreased during the trial. These facts suggested that net carbon production by 
plants (e.g. roots, excudates, etc) less than carbon mineralization.

There were also no significant compost effect on soil bulk density, total porosity, and available water content after amendement was applied but in general, all trials tended to increase total porosity, available water content and to decrease bulk density compared to the control. Reference [31] found that amaendement effects on bulk density and other soil physical properties take more than one year to manifest themselves. Some studies have shown that appication of compost significantly decrease bulk density [32] - [34]. Assuming constant soil particle density, bulk density decreasre due to compost addition imply increase total porosity as well.

The effect of compost on soil chemical properties are summarized in Tabel III.

TABLE III.

THE EFFECT OF COMPost ON SOIL CHeMicAL Properties

\begin{tabular}{|l|l|l|l|l|l|}
\hline $\begin{array}{l}\text { Compost } \\
(\mathrm{Mg} \text { ha-1 })\end{array}$ & $\mathrm{pH}$ & Total N & $\mathrm{P}$ & $\mathrm{K}$ & $\mathrm{CEC}$ \\
\cline { 3 - 6 } & $\%$ & $\mathrm{ppm}$ & $\mathrm{cmolkg}^{-1}$ & \\
\hline 0 & $5.05 \mathrm{a}$ & $0.16 \mathrm{a}$ & $15.98 \mathrm{a}$ & $0.23 \mathrm{a}$ & $6.16 \mathrm{a}$ \\
\hline 5 & $5.19 \mathrm{a}$ & $0.17 \mathrm{ab}$ & $20.08 \mathrm{ab}$ & $0.40 \mathrm{ab}$ & $6.33 \mathrm{ab}$ \\
\hline 10 & $\begin{array}{l}5.36 \\
\mathrm{ab}\end{array}$ & $0.18 \mathrm{bc}$ & $22.43 \mathrm{ab}$ & $0.54 \mathrm{bc}$ & $6,58 \mathrm{bc}$ \\
\hline 15 & $5.42 \mathrm{~b}$ & $0.19 \mathrm{bc}$ & $24.75 \mathrm{~b}$ & $0.58 \mathrm{c}$ & $6.78 \mathrm{c}$ \\
\hline 20 & $5.63 \mathrm{~b}$ & $0.20 \mathrm{c}$ & $35.65 \mathrm{c}$ & $0.72 \mathrm{c}$ & $7.01 \mathrm{c}$ \\
\hline
\end{tabular}

Values followed in the same column with the same letters are not significantly different at the 0.05 level

Application of compost affected significantly soil $\mathrm{pH}$, $\mathrm{CEC}, \mathrm{N}, \mathrm{P}$, and $\mathrm{K}$. Increases in rates of compost application caused enhancement of soil chemical properties. Enhancement of chemical properties occured due to the content of organic material in compost (TABEL I). Organic addition could cause organic carbon accumulation on the top soil [35]. Enhancement of soil organic carbon also increases soil humus or soil organic colloid which increase soil CEC [36], [37], [38]. Reference [39] showed, increases in soil chemical properties occures due to soil organic accumulation as a result of organic addition to soil and enhancement of microorganism which produces enzymes for degradation of organic materials. Mineralization of organic materials release inorganic $\mathrm{N}$ and $\mathrm{P}$ and other nutrients contained in organic materials [25]. Compost application increased soil $\mathrm{P}$ and $\mathrm{K}$ content compared to without compost application on planting maize, soybean, and wheat [40]. Reference [41] found that $\mathrm{K}$ in soil increased with organic decomposition. The increased of soil $\mathrm{pH}$ was probably due to the high $\mathrm{pH}$ value of the compost (TABEL I) [42].The highest soil $\mathrm{pH}$, $\mathrm{CEC}, \mathrm{N}, \mathrm{P}$, and $\mathrm{K}$ were founded with application of $20 \mathrm{Mg}$ ha $^{-1}$ compost.

Compost also affected the soil nutrient content. This was most evident for $\mathrm{N}$ and $\mathrm{P}$, which both increased with the addition of compost. This effect depended on the level of compost used and was more evident at the highest dosage. evel

\section{The Effect of Compost on Peanut Yield}

The effect of compost on peanut yield are summarized in Tabel IV. Compost application showed significant effect on pod dry weight of peanut. The increases of pod dry weight occured with increasing dosage of compost application. The highest pod dry weight was found with compost application of $20 \mathrm{Mg} \mathrm{ha}^{-1}$.

TABLE IV.

The EFFect Of COMPost On PEANUT YIELD

\begin{tabular}{|l|l|}
\hline Compost $\left(\mathrm{Mg} \mathrm{ha}^{-1}\right)$ & Pod dry weight $\left(\mathrm{g} \mathrm{plot}^{-1}\right)$ \\
\hline 0 & $169.51 \mathrm{a}$ \\
\hline 5 & $212.68 \mathrm{ab}$ \\
\hline 10 & $212.71 \mathrm{ab}$ \\
\hline 15 & $237.40 \mathrm{~b}$ \\
\hline 20 & $245.58 \mathrm{~b}$ \\
\hline
\end{tabular}

Values followed in the same column with the same letters are not significantly different at the 0.05 level

Enhancement of pod dry weight was caused by improvement of soil quality. Improvement of soil quality resulting from compost application occurs owing to increasing quality and quantity of organic matter and subsequently improves soil productivity [7]. Organic materials underwent degradadation that released nutrients such as $\mathrm{N}, \mathrm{P}, \mathrm{K}, \mathrm{Ca}$, and $\mathrm{Mg}$ to the soil available for plant uptake [39]. Compost application was caused higher nutrient soil content and higher nutrient availability due to the presence of increased amounts of organic matter in the soil [43].

Another reason may caused by increasing the ability of micro nutrient [44], increasing soil $\mathrm{pH}$ by decreasing $\mathrm{Al}$ cation that was formed by Al-organic compond with organic application [45], improving soil biological properties so that efficiency of nutrient uptake and plant yield were increased [40], content of plant hormone that function as stimulant [46].

\section{CONCLUSIONS}

Compost application did not improved soil physical properties but improved soil chemical properties and peanut yield. Improved soil chemical properties demonstated with increases in soil $\mathrm{pH}, \mathrm{CEC}, \mathrm{N}, \mathrm{P}$, and $\mathrm{K}$. The highst compost application $\left(20 \mathrm{Mg} \mathrm{ha}^{-1}\right)$ produced the best improvement of soil chemical properties and peanut yield.

\section{ACKNOWLEDGMENT}

We would like to thank Hardianti, Ikke Erwina, and Herlena for their assistance with field work and laboratory analyses.

\section{REFERENCES}

[1] BPS-Statistic Indonesia, Statistical Yearbook of Indonesia. BPSStatistic Indonesia, 2012.

[2] A. A. Freixo, P. L. O. D. Machado, H. P. Dos Santos, C. A. Silva, and F. D. Fadigas, "Soil organic carbon and fraction of a Rhodic Ferralsol under the influence of tillage and crop rotation systems in sourthern Brazil,"Soil \& Tillage Research, vol. 64, pp. 221-230, March 2002.

[3] F. Madrid, R. Lopez, and F. Cabrera, "Metal accumulation in soil after application of municipal solid waste compost under intensive farming conditions,"Agriculture Ecosystem \& Environment, vol. 119, pp. 249-256, March 2007.

[4] M. von Lutzow, J. Leifeld, M. Kainz, D. Kogel-Knabner, and J. C. Munch, "Indication for soil organic matter quality in soils under different management,"Geoderma, vol. 105, pp. 243-258, Feb. 2002.

[5] G. M. McAndrews, M. Liebman, C. A. Cambardella, and T. L. Richard, "Residual effects of composted and fresh solid swine (Sus scrofa L.) manure on soybean [Glycine max (L.) Merr.] growth and yield,"Agron. J., vol. 98, pp. 1128-1136, Jul-Augt. 2006. 
[6] M. Zhang, R. Gavlak, A. Mitchell, and S. Sparrow, "Solid and liquid cattle manure application in a subarctic soil,"Agron. J., vol. 98, pp. 1551-1558, Nov. 2006.

[7] C. Rivero, T. Chirenje, L. Q. Ma, and G. Martinez, "Influence of compost on soil organic matter quality under tropical conditions,"Geoderma, vol. 123, pp. 355-361, April 2004.

[8] J. W. Singer, S. J. Logsdon, and D. W. Meek, “Tillage and compost effects on corn growth, nutrient accumulation, and grain yield,"Agron. J., vol. 99, pp. 80-87, Jan. 2007.

[9] T. D'Hose, M. Cougnon, A. De Vliegher, K. Willekens, E. Van Bockstaele, and D. Reheul, "Farm Compost Application: Effects on crop performance,"Compost Science \& Utilization, vol. 20, pp. 4956, January 2012

[10] F. Tambone, P. Genevini, and F. Adani, "The effects of short-term compost application on soil chemical properties and on nutritional status of maize plant,"Compost Science \&Utilization, vol. 15, pp. 176-183, Sept. 2007.

[11] D. B. Oezenc and N. Oezenc, "Short-term effects of hazelnut husk compost and organic amendement applications on clay loam soil,"Compost Science \&Utilization, vol. 16, pp. 192-199, June 2008.

[12] M. J. Curtis and V. P. Claasen, "Regenerating topsoil functionality in four drastically disturbed soil types by compost incorporation,"Restor. Ecol., vol. 17, no. 1, pp. 24-32, 2009.

[13] B. J. Foley and L. R. Cooperband, "Paper mill residuals and compost effects on soil carbon and physical properties,"J. of Environmental Quality, vol. 31, pp. 2086-2095, Nov/Dec. 2002.

[14] M. Larcheveque, V. Badly, N. Montez, C. Fernandez, G. Bohnin, and C. Ballini, "Short-term effects on sewage sludge compost on a degraded mediterranean soil,"Soil Sci. Soc. Am. J., vol 70 no. 4, pp. 192-199, 2006

[15] M. Tejada, C. Garcia, J. L. Gonzales, and M. T. Hernandez, "Organic amendement based on fresh and composted beet vinasse: Influence on soil properties and wheat yield,"Soil Sci. Soc. Am. J., vol 70 no. 3, pp. $900-908,2006$.

[16] A. T. Well, K. Y. Chan, P. S. Cornish, "Comparison of conventional and alternative vegetable farming systems on the properties of a yellow earth in New South Wales,"Agriculture Ecosystem \& Environment, vol. 80, pp. 47-60, Augt. 2000.

[17] E. Arthur, W. Cornelis, and F. Razzaghi, "Compost amendement to sandy soil affects soil properties and greenhouse tomato productivity,"Compost Science \&Utilization, vol. 20, pp. 215-221, Oct. 2012 .

[18] R. M. Atiyeh, C. A. Edwards, S. Subler, and J. D. Metzger, "Pig manure vermicompost as a component of a horticultural bedding plant medium: effects on physicochemical properties and plant growth,"Bioresource Technology, vol. 78, pp. 11-20, May 2001.

[19] F. Muntemurro, M. Maiorana, G. Convertini, and D. Ferri, "Compost organic amendements in fodder crops: effects on yield, nitrogen utilization and soil characteristics,"Compost Science \&Utilization, vol. 14, pp. 114-123, March 2006

[20] G. Sarwar, H. Schmeisky, N. Hussain, S. Muhammad, M. Ibrahim, and E. Safdar, "Improvement of soil physical and chemical properties with compost application in rice-wheat cropping systems,"Pakistan Journal of Botany, Vol. 40 (1), pp. 275-282, 2008.

[21] T. J. Butler, D. C. Weindorf, K. J. Han, and J. P. Muir, "Dairy manure compost quality effects on corn silage and soil properties," Compost Science \&Utilization, vol. 17, pp. 18-24, Jan. 2009.

[22] R. G. Courtney and G. J. Mullen, "Soil quality and barley growth as influenced by the land application of two compost types," Bioresource Technology, vol. 99, pp. 2913-2918, May 2008.

[23] A. Y. Zahrim, A. R. Rakmi, and M. S. Kalil, "Sludge composting: A case study on palm oil mill sludge (POms),"Asean Journal of Chemical Engineering, vol. 7 (1\&2), pp. 102-110, 2007.

[24] J. W. C. Wong and M. Fang, "Effect of lime addition on sewage sludge composting process,"Water Research, vol. 34: 15, pp. 36913698, 2000

[25] P. L. Mafongoya, P. Barak, and J. D. Reed, "Carbon, nitrogen and phosphorus mineralisation of tree leaves and manure,"Biologi and Fertility of Soils, vol. 30 (4), pp. 298-305, 2000.

[26] P. Kumar, Tanafdar, C. Jagadish, Panwar, Jitendra, and K. Shyam, "A rapid method for assessment of plant residue quality,"Journal of Plant Nutrition and Soil Science., vol. 166, pp. 662-666, 2003.

[27] S. M. Contreras-Ramos, D. Alvares-Bernal, N. Trujillo-Tapia, and L. Dendooven, "Composting of tannery effluent with cow manure and wheat straw,"Bioresource Technology, vol. 94, pp. 223-228, Sept. 2004.
[28] B. J. Lindsay and T. J. Logan, "Field response of soil physical properties to sewage sludge,"J. Environ. Qual., vol. 27, pp. 534-542, May 1998.

[29] W. E. Curnoe, D. C. Irving, C. B. Dow, G. Valema, and A. Unc, “ Effect of spring application of a paper mill soil conditioner on corn yield,"Agron. J., vol. 98, pp. 423-429, April 2006.

[30] D. B. Ozenc, "Effects of composted huzelnut husk on growth of tomato plants,"Compost Science \&Utilization, vol. 14, pp. 271-274, Oct. 2006.

[31] L. M. Zibilske, W. M. Clapham, and R. V. Rourke, "Multiple applications of paper mill sludge in an agricultural system: soil effects,"J. Enviro. Qual., vol. 29, pp. 1975-1981, Oct. 2000.

[32] S. M. Pathan, L. A. G. Aylmore, and T. D. Colmer, "Properties of several fly ash materials in relation to use as soil amendement," $J$. Environ. Qual., vol. 32, pp. 687-693, March 2003.

[33] M. K. Shukla, R. Lal, and M. H. Ebinger, "Physical and chemical properties of a minespoil eight years after reclamation in Northeastern Ohio,"Soil Sci. Soc. Am. J., vol 69, pp. 1288-1297, July 2005

[34] A. N'Dayegamine, "Mixed paper mill sludge effect on corn yield, nitrogen efficiency, and soil properties,"Agron. J., vol. 98, pp. 14711478, Nov. 2006.

[35] P. Mantovi, G. Baldoni, and G. Toderi, "Reuse of liquid , dewatered, and composted sewage sludge on agricultural land: effect on longterm application on soil and crop,"Water Research, vol. 39, pp. 289296, 2005.

[36] K. H. Tan, Environmental Soil Science. Marcel Dekker, Inc. New York, 1994

[37] P. L. Giusquiani, M. Pagliai, G. Gigliotti, D. Businelli, and A. Benetti, "Urban waste compost: effects on physical, chemical, and biochemical soil properties,"J. Environ. Qual., vol 24, pp. 175-182, Jan. 1995.

[38] C. E. Johnson, "Cation exchange properties of acid forest soils of northeastern USA,"European Journal of Soil Science, vol. 53, pp. 271-182, June 2002

[39] M. de L. Adriano, F. Gutierrez, L. Dendooven, and M. SalvadorFigueroal, "Influence of compost and liquid bioferment on the chemical and biological characteristics of soil cultivated with banana (Musa spp. L),"Journal of Soil Science and Plant Nutrition, vol. 12(1), pp. 33-43, 2012.

[40] J. W. Singer, K. A. Kohler, M. Liebman, T. L. Richard, C. A Cambardella, and D. D. Buhler,'Tillage and compost affect yield of corn, soybean, and wheat,"Soil Fertility Agron. J, vol. 96, pp. 531537, 2004.

[41] H. Khademi and Z. Naderizadeh,"Mineralogical changes of clay sized phlogopite and muscovite as affected by organic matter amendement in rhizosphere,"Anadolu. J. Agric. Sci, vol. 25, pp. 7479, 2010.

[42] E. Ouedraogo, A. Mando, and N. P. Zombre, "Use of compost to improve soil properties and crop productivity under low inpu agricultural systems in West Africa,"Agric. Ecosyst. \& Environ., vol. 84, pp. 259-266, May 2001.

[43] Y. Chen and T. Aviad, "Effect of humic substances on plant growth. In: American Society of Agronomy and Soil Science Society of America (eds.), Humic substances in soil and crop sciences; Selected Readings. American Society of Agronomy, Madison, WI, pp. 161 $186,1990$.

[44] V. Balakrishnan, K. Venkatesan, and K. C. Ravindran, "The influence of halophytic compost, farmyard manure and phosphobacteris on soil microflora and enzyme activities,"Plant Soil Environ., vol. 53 (4), pp. 186-192, 2007.

[45] S. Winarso, E. Handayanto, Syekhfani, and D. Sulistyanto, "Pengaruh kombinasi senyawa humik dan $\mathrm{CaCO}_{3}$ terhadap aluminium dan fospat typic paleudult Kentrong banten,"J. Tanah Trop., vol 14 (2), pp. 89-95, 2009.

[46] L. Robles-Hernandez, A. C. Gonzalez-Francol, S. O. Guy, and W. C. Chun, "Liquid compost factor: a biologically derived seed treatment for increased grain chickpea production,"International Journal of Experimental Botany, vol. 78, pp. 129-134, 2009. 